\title{
THE COORDINATION ASPECT OF INSTITUTIONS IN THE CONTEXT OF AN EVOLUTIONARY APPROACH TO ECONOMIC DYNAMICS
}

\author{
Zoran Stefanovic* \\ Faculty of Economics, University of Nis, Nis, The Republic of Serbia
}

The paper provides an insight into the dominant trends of contemporary evolutionary economics and outlines the important issues related to the articulation of this approach in thinking about the economy. The paper also affirms a proposition on institutions as carrier structures of socio-economic evolution, whose numerous effects at the societal level are decoded through the coordination function. In addition to the market, the process of coordination also employs other non-market institutional structures, whose profile and operational principles are the product of the trajectories of cultural and historical evolution, different among social orders. Projects aimed at the transformation of the economic system are to be sensitized to an objectively conditioned diversity of the institutional structures of the world economy, and in this sense, should be very careful in the installation of "universal” reform solutions.

Keywords: generalized Darwinism, replicator, interactor, institutions, coordination

JEL Classification: B15, B25, B52, E02, E14

\section{INTRODUCTION}

The economy of today's, similar to other areas of social organization, is passing through an extremely dynamic era. Continuous pressures towards redesigning economic structures, shifts in power relations at different levels of the economy and increasingly regular excessive movements of economic flows undoubtedly put serious tasks before economic theory, for the most part still habituated to having a

\footnotetext{
* Correspondence to: Z. Stefanovic, Faculty of Economics, University of Nis, Trg kralja Aleksandra Ujedinitelja 11, 18000 Nis, The Republic of Serbia; e-mail: zoran.stefanovic@eknfak.ni.ac.rs
}

much more stable system, suitable for deliberation in equilibristic categories, as an object of observation.

There is a growing need to reflect the modern economy, given the presence, frequency and scope of the changes which it is exposed to, from the perspective that will take into account the dynamics as its substantial attribute. The conventional economic analysis, supported by the mechanistic conceptualization of the economy as a static, equilibrium system is an appropriate and logical approximation of the real economic system, with the proven educational and analytical values. However, it has become obvious that the metrics of modern, immanently dynamic economic processes elude concise conceptual relations of this 
undoubtedly powerful epistemological approach. Thus, an even modest step out of the orthodox economic epistemology into some of alternative views, which might be able to provide from reality a less remote and yet sufficiently rigorous conceptualization of economic reality, would be useful.

Beyond the boundaries of the mainstream of economic thought, evolutionary economics is a particularly popular epistemological orientation. As opposed to economic orthodoxy, which conceptually mimics classical physics, the above-mentioned approach mainly draws on the epistemological metaphor taken from the science of the evolution of biological systems. The generalization of the principle of evolution refers to a broad class of complex phenomena with the features of complex population systems, among which the economy can be counted as well. The economy is, therefore, perceived as a system whose dynamics takes place in accordance with the principles of the evolutionary variation, heredity and selection. The essential task in articulating this epistemological framework is to identify entities with quasi-genetic properties, which carry the evolution of the system. Evolutionary economics has not yet provided any unique answer to the aforementioned question, given the fact that different structures are proposed in order to fill this conceptual gap. Institutional structures certainly represent one of the possible solutions in the conceptualization of the "genetic" base of the economy. Institutions accumulate knowledge and provide recipes for the functioning of the system and socio-economic coordination, as its focal point. As the cardinal actor of coordination, the market is joined by other institutions, which, depending on the cultural circumstances, are differently established. Every socioeconomic order represents a mixture of coordination mechanisms shaped by cultural and historical circumstances, including both the market and nonmarket institutions. Capitalism, in this sense, can be understood as a kind of a family of different models of the market economy, whose individual coordinating properties and adaptability are based on the quality of relations between the market and other institutional structures, produced by cultural and historical evolution.
The goal of the paper is to provide an insight into the recent achievements of the streams of the economic evolutionary analysis, concentrated around these problems. In this sense, it begins with a detailed introduction to the evolutionary orientation in economic theory. Its origins are linked to the founder of the American institutional economics, Veblen, and his aspiration to establish economics as a "modern science", based on the Darwinian principles. The evolutionist moment, however, disappears from the latter flows of the institutional analysis. With the new formulation of the Darwinian approach within the science of the evolution of the living world, an interest in this epistemological approach began to emerge again. The breakthrough of the evolutionary metaphor into economics began in the early nineteeneighties. In the last four decades, the evolutionary principles have been elaborated in various fields of the economic analysis, in the absence of a common conceptual framework. After having reviewed the aforementioned economic-theoretical trends, this paper will present the efforts towards formulating the general epistemological base of the nowadays widely dispersed evolutionary analysis of the economy. One of the popular articulations of the evolutionary approach is, certainly, Generalized Darwinism. The paper will illustrate different views on the possible ways of the conceptualization of the aforementioned epistemological framework, regarding operational principles, structural relations and the relevant constitutive units. In this respect, the paper will sketch the concepts of Hodgson-Knudsen-Vanberg and Pelikan. An integral part of the paper will also be a critique of generalizing the Darwinian evolution as a model of thinking about the economy. The paper will also present an alternative theory of socio-economic evolution, which denies the Darwinian character of the evolutionary flows in society, embodied in the "continuity thesis". The final part of the paper outlines the role of institutions as a crucial element of socioeconomic evolution, with the major responsibilities in economic coordination. In this regard, the heterogeneous institutional structures that shape the coordination capacity of the society will also be taken into account. 
In accordance with the objectives of the paper, the general starting $\mathrm{p}$ of the analysis can be formulated through the following statement: the evolutionary approach to economic theory, understood in terms of thinking of the economy as an evolutionary system, based on the Darwinian principles of variation, heredity and selection, conceptually supported by institutions as approximation replicator structures, is an appropriate form of the conceptualization of the contemporary economic dynamics.

The paper will use methods suited to the research goals, particularly relying on the analytical description.

\section{VEBLENIAN ECONOMICS AND EVOLUTIONISM}

For more than a century, there have been efforts within economic theory to conceptualize the economy as a system subjected to the laws that are applied in the world of biological evolution. A pioneer of this orientation in economic theory, Veblen, considered the constitution of economics on the Darwinist starting points as a prerequisite of its transformation into a "modern" science. He considered the mainstream of the economic thought of his time to be a "preDarwinian" science, focused on the taxonomy of regular relations in the economy, whose theoretical framework eluded those forces that actually drive the economic process. None of the leading schools of the economic thought of the time was spared Veblen's charges for a lack of sensibility for the achievements of modern science. Marxism and the neoclassical school were accused of an inadequate, reductionist treatment of the "human material", relying on the individual as an economic actor, whose acting is over-determined by a collective, class influence (Marxism) or by essentially inert, hedonistic human nature (the individualism of the neoclassical and the Austrian schools). He was an opponent of the determinism present within the aforementioned schools of economic thought, in terms of the ability to predict the outcomes of socio-economic dynamics (Marxian predictions about revolution and equilibrium states in the neo-classical approach) (Veblen, 1998/1898, Hodgson, 1998).
T. Veblen searched for an epistemological framework which could enable the comprehension of the motional mechanisms of the socio-economic processes and at the same time help overcome the dichotomy between methodological individualism and collectivism. The reconstituted, post-Darwinian economic science should explain the process of cultural growth determined by economic interests as well as the cumulative succession of institutions within this process (Veblen, 1998/1898, 413). In this respect, Veblen considers that economics should be transformed into an evolutionary science, which has the evolution of institutions at the center of its occupation (Hodgson, 2008, 501). Veblen found the epistemological basis for such an orientation of the economic analysis in the conceptual framework of the theory of biological evolution. The economy is viewed as a collection of units subjected to the principles of variation, heredity and selection. First, there must be a diversity of units within a population (a variation), only to be followed by an inter-generational transfer of the properties of such individual units within the population (heredity), and, finally, a mechanism that enables better-adapted organisms to have a higher proportion of the population (the principle of natural selection) (Hodgson, 2008, 501-502). As far as Veblen understands it, the main unit of the evolutionary process is institutions - the evolution of socio-economic systems can be seen as a selection of the most properly adapted habits of a thought (institutions) (Hodgson, 2005, 906-907).

The immediate followers of the Veblenian tradition showed little enthusiasm for the development of the part of his learning about the evolution of institutions. Faced with the problems of measurement, Mitchell concluded that the conclusions Veblen had mentioned in this domain were of a speculative nature and equally difficult for empirical testing as the concepts of orthodoxy (Rutherford, 1998, 473). The research conducted by other institutionalists in the United States between the two world wars did not implement Veblen's ambitions, either, mostly for the reason of the fact that they were focused on studying the problems of companies and markets, the labor and social control of the economy, assuming a static institutional structure (Rutherford, 1998). An exception to this is the Common's concept of the purposeful selection 
of working rules as a method of regulating the US economy (Vanberg, 1997).

\section{THE DARWINIAN STREAM OF CONTEMPORARY ECONOMIC EVOLUTIONISM}

A sort of a wave of the implementation of the evolutionary framework in consideration of various problems of economic theory begins with the application of the Darwinian principles within the Neo-Schumpeterian analysis of the dynamics of companies and industries by Nelson and Winter (1982). The coming decades have experienced a kind of an expansion of the evolutionary analysis in terms of this approach being extended onto the different classes of economic problems: technological change, innovation systems, the study of the organization, economic growth etc. (Dollimore \& Hodgson, 2014). However, many self-proclaimed evolutionary studies do not actually use the Darwinist starting point. There is an absence of a general epistemological pattern, which increases the risk of the fragmentation of the evolutionary analysis (Dollimore \& Hodgson, 2014).

The revival of the interest in the evolutionary categories within economic theory itself was preceded by the consolidation of the Darwinian paradigm within the evolutionary science of the living world. In fact, until the nineteen-thirties, Darwinism was but one of the rival concepts of biological evolution. The alternative paradigms were Neo-Lamarckianism (which allows for the possibility of the inheritance of acquired characteristics), Orthogenesis (which holds that organisms are naturally predisposed to certain types of variations, which have no connection with adaptations to the environment) and Saltationism (according to which, new biological designs only occur after sudden, abrupt changes, whereas fine adjustments only improve already created designs) (Levit, Hossfeld \& Witt, 2011, 551-552). Only with the modern Darwinian synthesis, provided by the integration of classical, population and molecular genetics with microsystemics, which proved to be a very good match with the available paleontological data (Levit et al, 2011, 553), other explanations (except for Saltationism, which still has some influence) have decreased in importance.

The Darwinian paradigm studies the dynamics of populations of organisms as a result of a permanent adaptation to changes in the environment, followed by the differential survival of certain traits in the population, in the sense that better-adapted traits persist, which is provided by natural selection. The evolutionary process is supported by the principles of the variation (targeted or random) of characteristics within a population, heredity (a mechanism that ensures an inter-generational transfer of characteristics) and selection (the survival of betteradapted traits) (Hodgson, 1994, 113).

Modern Darwinism in biology can be formulated as a theory of how complex designs of living organisms can arise from unconscious algorithms of variation, selection and retention. The mechanism consists of a variation in the genotype (the construction codes of single organisms) and the selection of the phenotype - the selective retention of behaviors successful in obtaining resources from the environment. Selective retention operates through the "generation filter": the genes of organisms that are not successful in a struggle for survival or finding partners are lost in the next round (Dennett, 1995; Stoelhorst, 2008a).

Strictly speaking, the ontological starting point of Darwinism (in this case defined outside the biological sciences) consists of highlighting changes, their causality (in the sense that changes need to be explained), continuity (the current state is derived from earlier states), and their manifestation at several levels interconnected with each other, formed in accordance with the principle of emergence (the generation of new layers through the interaction of the layers of a lower order) (Stoelhorst, 2008b). Population thinking (the description of populations by the distribution of differences among the members of a population) (Hodgson, 1994) and system thinking (the observation of populations and individuals as complex systems that are constantly adapting to the environment) (Stoelhorst, 2008b) should be added to this. The main feature of the evolutionary view is the refusal of any determinism regarding the outcome of the process of evolution (Hodgson, 1995). 
Within evolutionary economics, attempts are made to adapt the starting propositions, the logic and the principles of the Darwinian approach to the study of economic reality and simultaneously translate them into an epistemological pattern that would become the framework for all, today fragmented, evolutionary branches of the economy. This epistemological pattern should naturally be quite sensitized to the specifics of the economic process.

The evolutionary viewpoint generally postulates that the economic process has properties of evolutionary dynamics. However, in interpreting the nature of economic evolution, the protagonists of the current streams of evolutionary economics diverge amongst themselves. In the most general sense, the subject of disagreement is the Darwinian nature of the evolution of the economy, which is contested within one branch of evolutionary economics. What certainly is not the subject of the dispute is the contextual nature of economic evolution. Given the fact that it takes place in real time, economic evolution is naturally "sensitive" to cultural, historical and socio-psychological circumstances (Dosi, 1991, 6).

The contemporary articulations of the Darwinian epistemological paradigm are to a significant extent met in the concept of "generalized Darwinism". Darwinism is transferred from biology to economics - therefore, in the beginning, attempts to elaborate this approach of economic reality first relied on the forms of the operation of the evolutionary principles in the biological world (Nelson \& Winter, 1982; Hodgson, 1993). Over time, however, a conclusion prevailed that the economy has too large a volume of specifics that prevent us from drawing direct analogies with biological phenomena. Instead of the forced placement of economic phenomena in biological Darwinian moulds, a more appropriate strategy for constituting the evolutionary economic paradigm was launched. In fact, without abandoning the original settings, Darwinism needs to be "purified" from all content-specific biological contents in order to arrive at some sort of conceptual substratum, which could serve as a universal epistemological model for the study of the phenomena whose dynamics has evolutionary characteristics. The resulting general framework should be further developed, specifically for each class of phenomena exposed to evolutionary dynamics, in accordance with the peculiar forms of its manifestation. This led to one of the leading evolutionary trends of economic thought known as "Generalized Darwinism" that is almost turning into a separate branch of evolutionary economics today (Dollimore \& Hodgson, 2014).

Generally speaking, generalized Darwinism combines efforts to generalize the Darwinian approach up to the level of an epistemological pattern suitable for the study of all the systems subjected to evolutionary dynamics and accordingly possessing very specific ontological unifying characteristics - biological, social and others. Accordingly, the so-called "Universal Darwinism" or "Generalized Darwinism" is supposed to describe the phenomena which have the properties of the so-called "Complex populations systems" (Hodgson, 2007, 265-266). Complex population systems should have the following characteristics: they are inhabited by populations of different individual units, faced with limited local resources and the problem of survival; adaptive solutions generated in the struggle for survival can be preserved over time and transferred to other individuals, through broadly defined mechanisms ensuring the operation of the principle of inheritance (Hodgson, 2007).

The articulation of Generalized Darwinism as the general epistemological framework in various complex population systems to which it can refer, must respect their peculiarities. In this sense, the elaboration of Generalized Darwinism in economic theory has the task of finding specific mechanisms, in accordance with the universal Darwinist principles, that shape the evolution of the economy. Accordingly, answers should be looked for to the questions relating to the mechanism of generating variation, natural selection mechanisms and criteria, the mechanism of inheritance etc. (Aldrich, Hodgson, Hull, Knudsen, Mokyr \& Vanberg, 2008, 584-585). A fundamentally important task is to determine the entity that "bears" economic evolution, whose viability is tested by selection pressure, observed in the long-run. This entity would need to have the ability to make an intergenerational transfer of its properties, similar to genes in biological evolution. It is the genotype, the principal "target" of evolution, while its immediate objects are specific 
units that carry the gene, presented by the phenotype in biology. In more modern evolutionary terms, these two entities are conceptualized as the replicator and the interactor (Aldrich et al, 2008). Replication is a causal relationship between entities where there is a substantial similarity between the original and replicated units and where the transfer of information about solutions related to survival also takes place. The replicator is an entity which transfers its structure mainly as "untouched" through successive replication (Hull, 1988, 408). On the other hand, the interactor is an entity that, as a cohesive unit, directly enters into reactions with the environment, in such a way that such an interaction becomes a differential (Hull, 1988, 408). The selection process is identified as the differential disappearance or proliferation of interactors, which ultimately leads to the differential perpetuation of the relevant replicator (Hull, 1988, 409), which occurs at the multiple, interconnected levels of the systems subjected to evolutionary dynamics.

Thus, the main actor in economic evolution should be the entity that is sufficiently durable, has the capability of replication and bears some solutions in a fight for survival. The popular version of evolutionary economics holds that the role of replicators is played by habits and routines, and that the major "candidates" for interactors are firms and similar organizations (Hodgson \& Knudsen, 2004). Habits are the disposition for certain types of behavior, which are generated by the repetition of thoughts or behaviors, and are stored in the human nervous system. These dispositions are converted into behavior only in certain circumstances. Habits are as dispositions sufficiently durable to be the subject of evolution, simultaneously having the capability of replication through imitation (Hodgson \& Knudsen, 2004, 286-289). The important determinants of the transformation of habits into a behavior are institutions. Social institutions stabilize and channel both habits and behavior (Hodgson \& Knudsen, 2004, 289). The routines are organizational dispositions that can stimulate certain patterns of the behavior of individuals within a group, in a form of a sequential response to cues. In organizations, some sort of mixing the habits of their members takes place in the sense that the habits of a member are the environment of another member, so that such an environment can stimulate some new behaviors that can lead to changes or the replication of parts of the environment (Hodgson \& Knudsen, 2004). Routines can be considered as sets of habits which, when triggered by circumstances, lead to a sequential behavior within a group. Let it again be noted that the habits and routines are subject to the evolutionary principles of variation, heredity and selection.

In the presented model, the survival of successful firms is simultaneously a selective retention of their business routines, which sequentially has a certain influence on the selection of the habits of those workers whose organizational dispositions the firm's routines are composed of, and therefore, ultimately, some sort of the selection of workers themselves, or their genetic structures, takes place (which is then equated with the "original" concept of biological evolution). Therefore, there are several sorts of replicators - routines, habits, genes - and levels at which selection works - companies and individuals. The specified selection string, even though it is exposed in this, quite a general form, implies in a sense the existence of a certain kind of synchronicity between biological and socio-economic evolution; when, however, considering the latter kind of evolutionary dynamics, selection flows at the level of the biological replicator can be ignored (Hodgson \& Knudsen, 2004, 302).

A particularly important role in the above-described conceptualization of Generalized Darwinism is played by habits, as a constitutional element of the relevant layers of a system exposed to evolutionary selection. First of all, habits are replication structures at the level of individuals as actors of socio-economic processes. Also, the coherently united habits of different individuals within a firm lead to a routine, as a higher replication entity. The concept of a habit within this approach is borrowed from the American philosophy of pragmatism and instinctive psychology, in terms of dispositions for certain types of behavior, which are acquired through various mechanisms of social interaction, where replication (although not perfect) is expressed at the phenotypic level (behavior) rather than the genotypic one (the genetically defined psychological states of individuals). A further clarification of the referred-to concept has found support in the concept of a program-based behavior. 
In the process of searching for sufficiently convincing alternative to the concept of rational choice, Vanberg (2002) utilizes the findings of various disciplines - evolutionary biology, epistemology, psychology and the theory of bounded rationality. The findings within these disciplines about human behavior lead to a conclusion that it is somehow coded, or programbased. All human capacity of decision making, concentrated in the human mind, has a threefold origin: genetic inheritance, personal experience and socio-cultural evolution. The available repertoire of decision-making skills is formed through the selective elimination of the behavior patterns that do not bring success. All the "wisdom" of humans, therefore, is a product of the past, derived from accumulated adaptations to earlier environments that were favored by evolutionary selection, while all increment in the existing knowledge results from breakthroughs from the existing gnoseological capacity based on the principle of trial and error (Campbell, 1965, cited in: Vanberg, 2002). Structures providing a support for human decision making are organized as some sort of programs, specialized for certain kinds of problems, including social relationships (among the important ones are those for detecting transactions and avoiding agents who cheat on obligations) (Vanberg, 2002, 37). An open question of what the relative presence of programs obtained by genetic heritage and those generated by personal learning and social-cultural experience in the human mind is still remains. In the context of the presented version of Generalized Darwinism, the concept of human consciousness as a modular structure composed of genetic instructions and social-cultural backgrounds can find its place in the explanation of habits. As the core feature of socioeconomic evolution, habits can be considered to be a special form of programs, in terms of findings from within the aforementioned disciplines (Aldrich et al, 2008, 590).

\section{CRITICS OF GENERALIZED DARWINISM AND THE CONTINUITY THESIS}

The presented generalization of the Darwinian paradigm and the manner it is adapted to the requirements of studying economic reality does not meet the widest support of the evolutionary research community within economic theory. Objections are related to the method of the construction of the aforementioned epistemological pattern as well as to the very concept of economic evolution as a process unfolding in accordance with the Darwinian model. To a considerable extent, the contestations of Generalized Darwinism in economic theory originate from the rival course of evolutionary thinking in economics, known as the continuity thesis.

The theoretical arguments supportive of the continuity thesis take a critical attitude towards the Darwinian mapping of the principles for the analysis of economic processes as their starting point. In this respect, the unjustified use of selection mechanisms in explaining economic evolution is pointed to (Cordes, 2007, 136141). First, the nature of adaptation mechanisms in the biological and the economic domains is different. While the adaptation of biological units is a product of random genetic mutations and sexual re-combinations, economic entities have an ability to directly and consciously react to impulses from the environment, thus being even capable of reducing selection pressure. Furthermore, treating firms as one of the forms of interactors in the economy as well as attributing replicator properties to routines are subjected to criticism, too. It is pointed out that companies are able to change their routines, whereas there is no possibility of such a relation between interactors and replicators in biological systems. Given their lack of durability, the understanding of routines as replicators is also problematic as they change in the business processes relatively quickly and rather frequently. As the principle objection, this line of thinking alleges the irrelevance of the concept of natural selection, as economic actors are able to consciously choose organizational forms ensuring them a survival, according to their own selection criteria. Accordingly, the protagonists of the continuity thesis criticize Generalized Darwinism because of the drawing of uncritical analogies between economic and biological processes (Witt, 2004, 128).

The fundamental theoretical starting point of the protagonists of the continuity thesis is the one of the existence of the ontological and the historical continuities between biological and cultural evolution, 
although their mechanisms are principally different. Cultural evolution takes place in accordance to specific patterns, but on the basis previously set by natural selection, and in the form of inherited human traits (Cordes, 2007, 141). Within this approach, evolution is defined as the self-transformation of a particular system guided by certain principles. During the phylogeny of the human species, natural selection has led to the formation of such a set of qualities that provide people with significantly higher rates of reproduction in relation to other species. As a result, selection pressure has significantly weakened, which, in turn, has led to the creation of conditions for the other types of evolution: cultural, economic and technological (Witt, 2004 132). The result of natural selection is that the inputs from the environment, materials and energy, are augmented by the genetic knowledge of people shaped by natural selection, which presents the input that self-transforms through the creation and diffusion of innovation. Increasing the human knowledge accumulating from one generation to another has had a decisive influence on production, thus generating economic evolution. The various means of the improvement of the expansion of human knowledge, amongst which are written communication, the invention of the printing technology and the modern means of the replication of knowledge have played an important role in the increase of such knowledge. . There is also a problem of an increasingly weak compatibility of the humangenerated flows of the material and energy flows with nature, which significantly limits possible future civilization effects of economic evolution (Witt, 2004, 141).

The proponents of the continuity thesis claim that the proposition of the homology between the biological and the economic processes, which according to the interpretation of this theoretical concept can logically be deduced from Generalized Darwinism, is not realistic. Also, it is emphasized that the Generalization of Darwinism in economics has shown little interest in the empirical confirmation of its own understanding of evolutionary dynamics (Levit et al, 2011).

As can be inferred from the presented views, the evolutionist stream of economic thought is actually a conglomeration of different views on the possible form of the process of evolution. It is certainly worth noting that the Darwinian version of economic evolutionism itself contains alternative conceptualizations of economic evolution (Pelikan, 2011).

\section{GROUP SELECTION, INSTITUTIONS AND ECONOMIC COORDINATION}

It should be noted at this point that, even when not viewed from a strictly Darwinian standpoint, economic evolution represents a multilevel process. All the entities that form the ontology of social processes are exposed to evolution. Consequently, one must take into account the evolutionary dynamics of those phenomena that reflect the collective dimension of the human activity. This leads to the problem of group selection, which still represents a major challenge for evolutionary theory. The central question is, in fact, the question of a possibility of the survival of a group, given the fact that, in evolutionary terms, groups are normally made of "selfish" individuals, whose survival combat will lead to the disintegration of the group. More specifically, a critical level of cooperation is required to suppress the selfishness of individuals to the level that would ensure the survival of the group. Looking through the current Darwinian schemata, if a group is the interactor, then there must be some kind of the replication structure providing an appropriate balance between the innate selfishness of the group members and the cooperation necessary for its survival, which is referred to as the problem of identifying the so-called „social replicators" (Campbell, 1965).

With no intention of elaborating further on the problem of group selection, it can be concluded that institutional structures can represent quite a convenient conceptual design in terms of finding a solution to a social replicator. Namely, the significant presence of regulatory mechanisms is needed to maintain the level of the cooperation of individuals necessary for the survival of the group, among which particularly important are those affecting the level of trust. Only in the behavioral regime characterized by a certainty regarding the behavior of partners in a social interaction, primarily in the field of obeying the rules, will actors be encouraged to make cooperative 
arrangements. Trust is a sort of the "invisible web" of the cooperative behavior of individuals within a group and as such is part of the informal institutional regulation. The importance of this feature of an institutional design is strongly confirmed in the sphere of economic transactions, which may significantly be hampered due to opportunistic behavior, a loosely set principal-agent relationship, asymmetric information etc. (Lekovic, 2012, 65). The level of trust necessary to maintain the cohesion of economic relations, however, itself depends on the support of other social institutions (Lekovic, 2012, 66). Therefore, even from these rather modest insights, one can gain some sense of the cardinal influence of the joint effect of institutional structures on economic evolution, and, linked to that, the differential survival of the economic „units" of different levels, which speaks in favor of electing institutions as a possible conceptual solution to replicators of economic process.

Although the founder of economic evolutionism, Veblen, considered institutions as the central theme of the evolutionary theory of economic change, in later Darwinian conceptualizations, they are partially displaced from the center of interest. It remains an open question whether the current intensity and diversification of the research grouped within the theoretical corpus of evolutionary economics will lead to progress in articulating the role of institutional structures in evolutionary dynamics or not. In this regard, the two other representative approaches tending to revitalize the role of institutions in the conceptualization of economic evolution will additionally be outlined here.

In a more recent version of his theory of economic evolution, Pelikan conceptualizes the economy as a set of agents at different ontological levels of the hierarchy. The agents of the higher order arise as emergent entities through the self-organization of the lower-order agents in networks (Pelikan, 2011). All agents have "built-in" behavior instructions in the form of rules. In the economy, the relevant agents are individuals, organizations and economies (Pelikan, 2011). Individuals have instructions in the form of their cognitive capacities obtained by genetic evolution and cultural experience, while the rules of organizations and those of the economy are represented by formal and informal institutions. Changes in institutional rules through trial and error represent evolution, while the internal dynamics of the network of agents at lower levels, within the framework of the existing institutions, is a process of economic development (Pelikan, 2011).

The protagonists of evolutionary macroeconomics consider the economy as a dissipative structure, which transforms an energy input into an output. The system is characterized by permanent imbalances as well as by a homeostasis, and continuous efforts are made to attract more energy in order to maintain the dynamics of the system (Foster, 2011). The disintegration of the system is prevented by meso rules, which provide short-term stable macroeconomic trends. These rules are hierarchically structured and can be identified with the institutions of the society (Foster, 2011). These rules are divided into physical, which provide knowledge of the transformation of energy inputs, on the one hand, and social, which dictate relations to other agents, on the other. Economic growth is only possible through an expansion of investments aimed at innovation, which is only possible by making a change in meso rules (Foster, 2011). In other words, the evolution of meso rules and institutions is closely associated with the path of the economic growth of different societies.

Independently of these considerations, if they may not exactly be identified as the bearers of economic evolution, social institutions may certainly be taken into consideration for their relatively usable approximation. Understood as the rules of the game in a society, structure the socio-economic interaction (North, 1994), institutions are a sort of an intersection of a multitude of functions essential for the economy - determining the behavior of its actors, providing communication channels between them, shaping the technological capacities of the society etc.

The central problem of the functioning of the economy is ensuring economic coordination. In his anthological elaboration of the mentioned issue, Hayek pointed to the impossibility of any individual or central authority to have the entirety of the economically relevant knowledge at their disposal. There is, however, a mechanism that enables the overcoming of the problem of economic actors' insufficient knowledge in this way or that, and enables putting somehow their 
action in order in the final outcome. It is the system of the market prices whose pulsing gives an insight into the relative scarcity of resources and is therefore indicative of economic actors' preferred direction of allocation (Hayek, 1948). By directing the allocation of resources towards various effective uses determined by the price system, in conditions of uncertainty and the actors' incomplete knowledge, the market provides an irreplaceable contribution to economic coordination and keeping the economy on stable, equilibrium trajectories. Hayek also points to other institutional structures which have spontaneously emerged and have been shaped in a long-lasting practice, which, in conjunction with the market, perform socio-economic coordination: the language, money, morality, law (Hayek, 1960). Hayek's more than effective analysis threw light on coordination as the essential function of institutional structures. The crucial mechanism of economic coordination is definitely the market mechanism, supported by other social institutions. Similarly to the market, they somehow "decipher" the environment, creating actors' perceptions of how the environment is structured and which preferred forms of action are. By providing some sort of information shelter for actors in conditions of uncertainty, institutions compensate for their cognitive limits and, in a way, make a meaningful economic action possible (North, 1981).

Accordingly, each economy can be regarded as a distinctive combination of markets and other institutions in the service of socio-economic coordination. The contemporary economy is inhabited by numerous and richly differentiated non-market institutions, heterogeneous by origin and different in coordination effects, which reflects the different paths of the cultural and historical evolution of individual societies. Despite being an omnipresent and undoubtedly dominant coordination structure, the market itself does not represent a "natural” category, but is only part of a collection of institutions emerged in the process of socio-economic evolution. Moreover, the market mechanism is the subject of continuous societal interventions, aimed at shaping its multilateral impacts in accordance with social interests. Various institutional capacities are included in collective efforts to limit, to a certain extent, the influence of the market on the socially acceptable distribution of power between relevant economic actors. For example, non-market institutions (especially judicial ones) can be employed in the process of finding fair rules for resolving permanent conflicts generated by the market exchange (Commons, 1968/1924, in: Vanberg, 1997). Non-market institutional structures themselves represent some sort of a society's defense from social destruction that, in certain stages of civilization, is naturally caused by the generalization of the market mechanism (Polanyi, 1944). The comprehension of the market as a natural, super-institutional entity mystifies the actual manner of its functioning, which, in a real economy, is to a certain extent stamped by cultural and historical circumstances (Dugger, 2005).

\section{CONCLUSION}

In terms of the material presented, the starting point of the paper is shown to be sustainable. Even independently of the arguments presented in the paper, the various branches of the economic analysis have detected the existence of various institutional structures, which, in conjunction with the market, enable economic coordination at various levels of the economy. Induced by selection pressure, their dynamics is to a lesser or greater extent a trajectory dependent phenomenon, which is labeled as „path dependency" by the conventional economic analysis. A wave of neoliberal reforms, aimed at the absolutization of the market mechanism, bears a considerable destructive potential, given the fact that the frontal attack on the existing diverse non-market institutions in the world economy threatens to seriously reduce its future adaptive capacity.

The valuation of institutional structures within the evolutionary stream of economic thought may still not fully reflect their versatile and capital influence on the evolution of the economy. A more intense sensitization to the institutional component of economic evolution may be helpful in expanding the effectiveness of evolutionary thinking of the economy. Some of the research orientations, significantly conscious in the aforementioned sense, are the evolutionary theory of economic growth, the comparative political economy, the theory of the national innovation system etc. Economic policies must also understand possible 
implications of this element of the economic process in order to channel their perceived dynamics within the limits of the possible, in accordance with the needs of economic development.

One should not, however, expect a serious penetration of the evolutionary approach into the mainstream of economic thought. First, beside quite a general epistemological framework, the convergence of the alternative versions of economic evolutionism into a uniform and consistent paradigmatic framework is not on the horizon. Irrespective of this, the problem is also the reception of the approach by economic orthodoxy, responsible for the dissemination of topics and ideas through the majority of the economic theory community, which is showing little interest in the concepts that have not gone through a rigorous mathematical formalization. The evolutionary approach, however, remains very convenient in circumstances where it is necessary that the conventional economic analysis should be gone beyond, to the study of real economic systems, whose dynamics is context-specific and subject to culturalhistorical regularities. In line with this, the reflection of the economy within the evolutionist frameworks can be a suitable point of orientation of the economic policy.

\section{ACKNOWLEDGMENTS}

This paper is part of the research Project (No. 179066), which is funded by the Ministry of Education, Science and Technological Development of the Republic of Serbia.

\section{REFERENCES}

Aldrich, H. E., Hodgson, G. M., Hull, D. L., Knudsen, T. Mokyr, J., \& Vanberg, V. J. (2008). In Defence of Generalized Darwinism. Journal of Evolutionary Economics, 18(5), 577-596. doi: 10.1007/s00191-008-0110-z

Campbell, D. T. (1965). Variation and Selective Retention in Sociocultural Evolution. In H. R. Barringer, G. I. Blankstein, \& R. W. Mack, (Eds.), Social Change in Developing Areas: A Reinterpretation of Evolutionary Theory. Cambridge M.A.:
Schenkman.

Commons, J. 1968 (1924). Legal Foundations of Capitalism. Madison: The University of Wisconsin Press.

Cordes, C. (2007). Turning Economics into an Evolutionary Science: Veblen, the Selection Metaphor, and Analogical Thinking. Journal of Economic Issues, 41(1), 135-154.

Dennett, D. C. (1995). Darwin's Dangerous Idea: Evolution and the Meanings of Life. London, UK: Penguin Books.

Dollimore, D., \& Hodgson, G. (2014). Four Essays on Economic Evolution: An Introduction. Journal of Evolutionary Economics, 24(1), 1-10. doi: 10.1007/s00191-013-0315-7

Dosi, G. (1991). Some Thoughts on the Premises, Challenges and Dangers of an Evolutionary Perspective in Economics. Journal of Evolutionary Economics, 1(1), 5-7.

Dugger, W. M. (2005). Dugger's Theorem: The Free Market is Impossible: Remakrs upon Receiving the Veblen-Commons Award. Journal of Economic Issues, 39(2), 309-324.

Foster, J. (2011). Evolutionary Macroeconomics: A Research Agenda. Journal of Evolutionary Economics, 21(1), 5-28. doi: 10.1007/s00191-010-0187-z

Hayek, F. (1948). Individualism and Economic Order. Chicago, USA: University of Chicago Press.

Hayek, F. (1960). The Constitution of Liberty. Chicago. USA: University of Chicago Press.

Hodgson, G. M. (1993). Economics and Evolution: Bringing Life Back into Economics. Michigan, USA: University of Michigan Press.

Hodgson, G. M. (1994). Economic Evolution and Natural Selection. In G. M., Hodgson, W. J., Sammuels, \& M. R.Tool, (Eds.), The Elgar Companion to Institutional and Evolutionary Economics. Cheltenham, Northampton: Edward Elgar Publishing.

Hodgson, G. M. (1995). The Evolution of Evolutionary Economics. Scottish Journal of Political Economy, 42(4), 469-488. doi:10.1111/j.1467-9485.1995.tb01172.x

Hodgson, G. M. (1998). On the evolution of Thorstein Veblen's evolutionary economics. Cambridge Journal of Economics, 22(4). 415-431.

Hodgson, G. M. (2007). A Response to Christian Cordes and Clifford Poirot. Journal of Economic Issues, 41(1), 265-276.

Hodgson, G. M. (2008). How Veblen Generalized Darwinism. Journal of Economic Issues, 42(2), 399-405. 
Hodgson, G. M., \& Knudsen, T. (2004). The Firm as an Interactor: Firms as Vehicles for Habits and Routines. Journal of Evolutionary Economics, 14(3), 281-307. doi: 10.1007/s00191004-0192-1

Hull, D. L. (1988). Science as a Process: An Evolutionary Account of the Social and Conceptual Development of Science. Chicago, USA: The University of Chicago Press Books.

Lekovic, V. (2012). Trust as an institutional factor of economic success. Economic Horizons, 14(2), 65-78. doi: 10.5937/ ekonhor1202063L

Levit, G., S., Hossfeld, U., \& Witt, U. (2011). Can Darwinism be "Generalized" and of what use would this be? Journal of Evolutionary Economics, 21(4), 545-562. doi: 10.1007/s00191011-0235-3

Nelson, R. (2002). Bringing Institutions into Evolutionary Growth Theory. Journal of Evolutionary Economics, 12(1-2), 1728. doi: 10.1007/s00191-002-0108-x

Nelson, R., \& Winter, S. (1982). Evolutionary Theory of Economic Change. Cambridge Mass. and London: The Belknap Press of Harvard University Press.

North, D. C. (1981). Structure and Change in Economic History. New York, NY: London, UK: W. W. Norton Company.

North, D. C. (1990). Institutions, Institutional Change and Economic Performance. Cambridge, USA: Cambridge University Press.

North, D. C. (1994). Economic Performance through Time. American Economic Review, 84(3), 359-368.

Pelikan, P. (2003). Bringing Institutions into Evolutionary Economics: Another View with Links to Changes in Physical and Social Technologies. Journal of Evolutionary Economics, 13(3), 237-258. doi: 10.1007/s00191-003-0157-9
Pelikan, P. (2011). Evolutionary Developmental Economics: How to generalize Darwinism Fruitfully to help comprehend Economic Change. Journal of Evolutionary Economics, 21(2), 341-366. doi: 10.1007/s00191-010-0178-0

Polanyi, K. (1944). The Great Transformation: The Political and Economic Origins of Our Time. Boston, USA: Beacon Press.

Rutherford, M. (1998) Veblen's Evolutionary Programme: A Promise Unfulfilled. Cambridge Journal of Economics, 22(4), 463-477

Stoelhorst, J. W. (2008a). Generalized Darwinism from the Bottom Up: An Evolutionary View of Socio-Economic Behavior and Organization. In W. Elsner, \& H. Hanappi, (Eds.), Advances in Evolutionary Institutional Economics: Evolutionary Mechanisms, Non-Knowledge, and Strategy (pp. 35-58). Cheltenham: Edward Elgar Publishers.

Stoelhorst, J. W. (2008b) The Explanatory Logic and Ontological Commitments of Generalized Darwinism. Journal of Economic Methodology, 15(4), 343-363. doi: 10.1080/13501780802506661

Vanberg, V. J. (1997). Institutional Evolution through Purposeful Selection: The Constitutional Economics of John R. Commons. Constitutional Political Economy, 8(2), 105-122. doi: 10.1023/A:1009030324594

Vanberg, V. J. (2002). Rational Choice vs. Program-Based Behavior: Alternative Theoretical Approaches and their Relevance for the Study of Institutions. Rationality and Society, 14(1), 7-54. doi: 10.1177/1043463102014001002

Veblen, T. (1998/1898). Why is Econonomics not an Evolutionary Science. Cambridge Journal of Economics, 22(4), 403-414.

Witt, U. (2004). On the Proper Interpretation of „Evolution" in Economics and its Implications for Production Theory. Journal of Economic Methodology, 11(2), 125-146. doi: 10.1080/13501780410001694091

Received on $15^{\text {th }}$ June 2015, after revision, accepted for publication on $17^{\text {th }}$ August 2015.

Published online on $25^{\text {th }}$ August 2015

Zoran Stefanovic is an Associate Professor at the Department of General Economic Theory of the Faculty of Economics of the University of Niš. He teaches the subjects of Economic Doctrines and the Economics of Transition (in the undergraduate studies), Contemporary Economic Theories (in the Master's studies) and Transition of Post-Socialist Economies (in the doctoral studies). The major fields of his research interest are contemporary economic paradigms, the economics of post-socialist transition and the political economy of globalization. 


\title{
KOORDINACIONI ASPEKT INSTITUCIJA U KONTEKSTU EVOLUCIONIONISTIČKOG PRISTUPA EKONOMSKOJ DINAMICI
}

\author{
Zoran Stefanović* \\ Ekonomski fakultet Univerziteta u Nišu
}

\begin{abstract}
Rad pruža uvid u dominantne tokove savremene evolucionističke ekonomije i skicira važnije probleme vezane za artikulaciju pomenutog pristupa u promišljanju privrede. $\mathrm{U}$ radu se, takođe, zastupa stav o institucijama kao nosećim strukturama društveno-ekonomske evolucije, čiji se brojni efekti na nivou društva očitavaju kroz funkciju koordinacije. Proces koordinisanja upošljava, pored tržišta, i druge institucionalne strukture, čiji su profil i operativna načela produkt tokova kulturno-istorijske evolucije, osobenih za svaki društveni poredak. Projekti usmereni ka transformaciji ekonomskog sistema, moraju biti senzibilisani na objektivno uslovljenu raznorodnost institucionalnih strutkura u svetskoj privredi, i, u tom smislu, veoma oprezni u instaliranju „univerzalnih“ reformskih rešenja.
\end{abstract}

Ključne reči: generalizovani darvinizam, replikator, interaktor, institucije, koordinacija

JEL Classification: B15, B25, B52, E02, E14

\section{UVOD}

Privreda današnjice, slično ostalim oblastima društvene organizacije, prolazi kroz izrazito dinamičnu epohu. Neprekidni pritisci ka redizajniranju ekonomskih struktura, prisutna pomeranja u relacijama moći na različitim nivoima privrede, sve regularnija ekscesna kretanja privrednih tokova, stavljaju nesumnjivo ozbiljne zadatke pred ekonomsku teoriju, većim delom ipak naviknutu da kao predmet posmatranja ima daleko stabilniji sistem, koji se može promišljati u ekvilibrističkim kategorijama.

\footnotetext{
* Korespondencija: Z. Stefanović, Ekonomski fakultet Univerziteta u Nišu, Trg kralja Aleksandra Ujedinitelja 11, 18000 Niš, Republika Srbija; e-mail: zoran.stefanovic@eknfak.ni.ac.rs
}

Sve je prisutnija potreba da se savremena privreda, s obzirom na prisustvo, frekvenciju i obuhvat promena kojima je izložena, promišlja iz perspektive koja će uzeti u obzir dinamiku kao njen suštinski atribut. Konvencionalna ekonomska analiza, koja oslonac nalazi u mehanističkoj konceptualizaciji privrede kao statičkog, ravnotežnog sistema, predstavlja prikladnu i logičnu aproksimaciju realnog ekonomskog sistema, sa dokazanom edukativnom i analitičkom vrednošću. Međutim, sva je prilika da metrika savremenih, imanentno dinamičnih ekonomskih procesa, izmiče egzaktnim konceptualnim relacijama ovog neosporno moćnog epistemološkog pristupa. Prema tome, koristan bi bio makar i ogledni iskorak iz ortodoksne ekonomske epistemologije, ka nekom od alternativnih gledišta, koje bi, možda, bilo u mogućnosti da pruži od 
realnosti manje udaljenu, a opet dovoljno rigoroznu konceptualizaciju privredne stvarnosti.

Van granica matice ekonomske misli, naročito popularnu epistemološku orijentaciju predstavlja evolucionistička ekonomija. Pomenuti pristup, suprotno ekonomskoj ortodoksiji, koja konceptualno podražava klasičnu fiziku, većinski se naslanja na epistemološku metaforu preuzetu iz nauke o evoluciji bioloških sistema. Generalizacija principa evolucije odnosi se na široku klasu fenomena sa kararakteristikama kompleksnih populacionih sistema, u koje se može svrstati i privreda. Privreda se, shodno tome, posmatra kao sistem čija se dinamika odvija u skladu sa evolutivnim principima varijacije, herediteta i selekcije. Suštinski zadatak u artikulisanju pomenutog epistemološkog okvira predstavlja identifikacija entiteta sa kvazigenetskim svojstvima, koji nosi evoluciju sistema. Evolucionistička ekonomija još uvek nema jedinstven odgovor na pomenuto pitanje, s obzirom na to da se predlažu različitie strukture za popunu ove konceptualne praznine. Institucionalne strukture, svakako, predstavljaju jedno od mogućih rešenja u konceptualizaciji "genetske" osnovice privrede. Institucije akumuliraju znanje i obezbeđuju recepturu za funkcionisanje sistema, odnosno, društveno-ekonomsku koordinaciju, kao njegovu težišnu odrednicu. Tržištu, kao kardinalnom akteru koordinacije, pridružene su i druge institucije, koje su u svakoj privredi, u zavisnosti od kulturoloških okolnosti, različito postavljene. Svaki društveno-ekonomski poredak predstavlja kulturalnoistorijski oblikovan spoj koordinacionih mehanizama: tržišta i netržišnih institucija. Kapitalizam se, u tom smislu, može shvatiti kao svojevrsna porodica različitih modela tržišne privrede, čija pojedinačna koordinaciona svojstva i adaptibilnost počivaju na kvalitetu uređenja odnosa između tržišta i drugih institucionalnih struktura, produkovanih kulturalnoistorijskom evolucijom.

Cilj rada je pružanje uvida u skorašnja dostignuća tokova ekonomske analize koncentrisane oko pomenutih problema.

$\mathrm{U}$ tom smislu, najpre se daje detaljan prikaz evolucionističke orijentacije $\mathrm{u}$ ekonomskoj teoriji. Njeni počeci vezuju se za rodonačelnika američke institucionalne ekonomije, T. Veblen-a, i njegovu težnju da ekonomiju koncipira kao „modernu nauku“, zasnovanu na darvinističkim principima. Evolucionistički momenat, međutim, iščezava iz potonjih tokova institucioanalne analize. Sa novom formulacijom darvinističkog pristupa $u$ nauci o evoluciji živog sveta, interesovanje za ovaj epistemološki obrazac se obnavlja, da bi svoj ponovni prodor u ekonomsku nauku, evolucionistička metafora počela da ostvaruje početkom osamdesetih godina XX veka. U poslednje četiri decenije, evolucionistička načela se razrađuju u različitim oblastima ekonomske analize, u odsustvu zajedničkog konceptualnog okvira. Nakon uvida u pomenute ekonomskoteorijske tokove, $\mathrm{u}$ radu se prikazuju nastojanja ka iznalaženju epistemološke osnovice danas široko razuđene evolucionističke analize $u$ ekonomiji. Jedna od popularnih artikulacija evolucionističkog pristupa, svakako, je generalizovani darvinizam. U radu će biti ilustrovana različita gledišta o tome kako bi pomenuti epistemološki okvir trebalo da bude konceptualizovan: u domenu operativnih načela, strukturnih relacija, relevantnih konstitutivnih jedinica. $U$ tom smislu, biće prikazana shvatanja Hodžson-Knudsen-Vanbergove grupe i P. Pelikan-a. Sastavni deo prikaza biće i kritika generalizovanog darvinizma, kao modela promišljanja evolucije privrede. Biće učinjen osvrt i na i alternatvnu teoriju društveno-ekonomske evolucije, koja negira darvinistički karakter evolucionih tokova u društvu, otelotvorena $u$ "tezi o kontinuitetu“. Završni deo rada skicira ulogu institucija kao kardinalnog elementa društveno-ekonomske evolucije, zaduženog, ponajviše, za ekonomsku koordinaciju. Ukazuje se, s tim u vezi, i na heterogene institucionalne strukture koje oblikuju koordinacioni kapacitet društva.

U skladu sa navedenim, generalno polazište rada može se formulisati kroz sledeću postavku: evolucionistički pristup u ekonomskoj teoriji, shvaćen $\mathrm{u}$ smislu promišljanja privrede kao evolucionog sistema, zasnovanog na darvinističkim načelima varijacije, herediteta i selekcije, konceptualno potpomognut institucijama kao aproksimacijom replikatorskih struktura, predstavlja prikladnu formu konceptualizacije savremene privredne dinamike.

U radu će biti korišćene metode primerene postavljenom cilju istraživanja, uz naročiti oslonac na analitičku deskripciju. 


\section{VEBLENOVSKA EKONOMIJA I EVOLUCIONIZAM}

Već više od jednog veka, prisutna su nastojanja unutar ekonomske teorije da se privreda konceptualizuje kao sistem podložan zakonitostima koje važe u svetu biološke evolucije. Pionir ove orijentacije u ekonomskoj teoriji, T. Veblen, konstituisanje ekonomije na darvinističkim polazištima smatrao je preduslovom njenog prevođenja $u$ "moderne" nauke. Maticu ekonomske misli svoga doba smatrao je "preddarvinističkom" naukom, usmerenom na taksonomiju zakonitih relacija u privredi, čijem teorijskom okviru izmiču one snage koje, zapravo, pokreću ekonomski proces. Nijedan od onovremenih pravaca ekonomske misli nije bio pošteđen $\mathrm{T}$. Veblenovih optužbi za nedostatak senzibliteta prema tekovinama moderne nauke. Marksizmu i neoklasičnoj školi prebacivao je zbog neadekvatnog, redukcionističkog tretmana "ljudskog materijala“, odnosno, pojedinca kao ekonomskog aktera, čije je delanje naddeterminisano kolektivnim, klasnim uticajem (marksizam), ili suštinski inertnom, hedonističkom ljudskom prirodom (individualizam neoklasike i austrijske škole). Bio je protivnik i determinizma prisutnog kod pomenutih pravaca ekonomske misli, u smislu mogućnosti projekcije ishoda društveno-ekonomske dinamike (revolucija kod marksista i ravnoteža kod neoklasike) (Veblen, 1998/1898; Hodgson, 1998).

T. Veblen traga za epistemološkim okvirom uz pomoć kojeg bi mogli da se spoznaju pokretački mehanizmi društveno-ekonomskog procesa i, istovremeno, prevazišla dihotomija između metodološkog kolektivizma i individualizma. Rekonstituisana, postdarvinistička ekonomska nauka trebalo bi da objasni proces kulturnog rasta determinisanog ekonomskim interesima, kao i kumulativnu sukcesiju institucija unutar tog procesa (Veblen, 1998/1898, 413). U tom smislu, T. Veblen smatra da ekonomija treba da se transformiše $u$ evolucionističku nauku, koja $u$ središtu svog interesovanja ima evoluciju institucija (Hodgson, 2008, 501). Epistemološku osnovicu za tako orijentisanu ekonomsku analizu, T. Veblen pronalazi $\mathrm{u}$ konceptualnom okviru biološke teorije evolucije. Privreda se posmatra kao skup jedinki podložnih principima varijacije, herediteta i selekcije. Najpre mora postojati različitost jedinki unutar populacije (varijacije), intergeneracijski transfer osobina jedinki unutar populacije (hereditet), i, konačno, mehanizam koji omogaćava da bolje adaptirani organizmi imaju veću proporciju u populaciji (princip naturalne selekcije) (Hodgson, 2008). Glavna jedinica evolucionog procesa, shodno T. Veblen-ovom shvatanju, upravo su institucije - evolucija društveno-ekonomskih sistema može se shvatiti kao selekcija najadaptiranijih navika mišljenja (institucija).

Neposredni sledbenici veblenovske tradicije nisu pokazivali preveliki entuzijazam za razradu dela njegovog učenja o evoluciji institucija. Suočen sa problemima merenja, V. Mičel zaključuje da su T. Veblen-ovi stavovi u pomenutom domenu spekulativne prirode i jednako teški za empirijsko testiranje kao i koncepcije ortodoksije (Rutherford, 1998, 473). Ni istraživanja ostalih institucionalista u SAD između dva svetska rata nisu realizovala $\mathrm{T}$. Veblen-ove ambicije, s obzirom na to da su bila fokusirana na proučavanje problema firmi i tržišta, radne snage i društvene kontrole privrede, podrazumevajući statičnu institucionalnu strukturu (Rutherford, 1998). Izuzetak je J. Komonsova koncepcija svrsishodne selekcije radnih pravila, kao metod regulisanja američke privrede (Vanberg, 1997).

\section{DARVINISTIČKI TOK SAVREMENOG EKONOMSKOG EVOLUCIONIZMA}

Svojevrsni talas primene evolucionističkog okvira $\mathrm{u}$ promišljanju raznih problema ekonomske teorije počinje sa primenom darvinističkih načela $\mathrm{u}$ neošumpeterovskoj analizi dinamike firmi i industrija, R. Nelson-a i S. Winter-a (1982). U toku narednih decenija, evolucionistička analiza doživljava svojevrsnu ekpsanziju, u smislu širenja na različite klase ekonomskih problema: tehnološke promene, inovacioni sistemi, nauka o organizaciji, privredni rast i sl. (Dollimore \& Hodgson, 2014). Međutim, mnoge proklamovano evolucionističke studije se, zapravo, ne koriste darvinističkim polazištima. Uočava se odsustvo generalnog epistemološkog obrasca, što povećava rizik 
od fragmentacije evolucionističke analize (Dollimore \& Hodgson, 2014).

Oživljavanju interesovanja za evolucionističke kategorije unutar ekonomske teorije prethodilo je konsolidovanje same darvinističke paradigme unutar nauke o evoluciji živog sveta. Naime, sve do tridesetih godina XX veka, darvinizam je bio samo jedna od rivalskih koncepcija biološke evolucije. Alternativne paradigme bile su neo-lamarkijanizam (koji, pored urođenih, dozvoljava mogućnost nasleđivanja i stečenih osobina), ortogeneza (koja smatra da su organizmi prirodno predodređeni za određene vrste varijacija, koje nemaju veza sa adaptacijama na okruženje) i saltacionisitička (prema kojoj se novi biološki dizajni javljaju samo nakon naglih, skokovitih promena, dok se sitnim prilagođavanjima samo usavršavaju tako stvorene strukture) (Levit, Hossfeld \& Witt, 2011, 551552). Tek sa modernom darvinističkom sintezom, koja je obezbedila integraciju klasične, populacione i molekulske genetike sa mikrosistematikom, koja se dobro uklopila sa raspoloživim paleontološkim podacima (Levit et al, 2011, 553), ostala objašnjenja (osim saltacionističkog, koje još uvek ima određenog uticaja) izgubila su na značaju.

Darvinistička paradigma proučava dinamiku populacije organizama kao rezultat permanentnih adaptacija na promene u okruženju, koju prati diferencijalni opstanak određenih osobina unutar populacije, u smislu da bolje adaptirane osobine opstaju, što omogućava prirodna selekcija. Evolucioni proces podupiru principi varijacije (ciljane ili slučajne) osobina unutar populacije, herediteta (mehanizam koji obezbeđuje intergeneracijski transfer osobina) i selekcije (opstanak bolje adaptiranih osobina) (Hodgson, 1994, 113).

Savremeni darvinizam u biologiji može se formulisati kao teorija o tome kako kompleksni dizajni živih organizama mogu nastati iz nesvesnog algoritama varijacije, selekcije i retencije. Mehanizam se sastoji od varijacija u genotipu (kod za izgradnju organizma), i selekcije fenotipa, oblika ponašanja uspešnog u pribavljanju resursa iz okruženja. Selektivna retencija deluje kroz "generacioni filter", geni organizama koji nisu uspešni u borbi za opstanak ili nalaženje partnera za opstanak su izgubljeni za sledeću rundu (Dennett, 1995; Stoelhorst, 2008a).

Strogo posmatrano, ontološka polazišta darvinizma (istina definisana van biološke nauke), sastoje se $u$ isticanju promena, njihovoj uzročnosti ( $\mathrm{u}$ smislu da se promene moraju objasniti), kontinuitetu (sadašnje stanje izvodi se iz ranijih), i njihovom ispoljavanju na više međusobno povezanih nivoa, koji nastaju saglasno načelu emergencije (nastajanje novih slojeva kroz interakciju slojeva nižeg reda) (Stoelhorst, 2008b, 344-345). Tome treba dodati populaciono mišljenje (opisivanje vrste prema distribuciji razlika kod članova populacije) (Hodgson, 1994), kao i sistemski pristup (posmatranje populacija i jedinki kao kompleksnih sistema koji se neprekidno adaptiraju na okruženje) (Stoelhorst, 2008b). Bitno obeležje evolucionističkog mišljenja je i odbijanje bilo kakvog determinizma u pogledu ishoda procesa evolucije (Hodgson, 1995).

Unutar evolucionističke ekonomije traju pokušaji da se polazišta, logika i principi darvinističkog pristupa adaptiraju na proučavanje privredne stvarnosti i pretoče $u$ epistemološki obrazac koji bi postao okvir za sve, danas gotovo fragmentisane, grane evolucionističke ekonomije. Taj bi obrazac, naravno, morao da bude sasvim senzibilisan na specifičnosti ekonomskih procesa.

Evolucionističko stanovište, generalno, podrazumeva da ekonomski proces ima svojstva evolucione dinamike. Međutim, u tumačenju prirode ekonomske evolucije, protagonisti ovog toka ekonomske teorije se razilaze. U najopštijem smislu, predmet razilaženja je darvinistički karakter evolucije privrede, koji se osporava unutar jednog dela evolucionističke ekonomije. Ono što, naravno, nije predmet spora je kontekstualna priroda ekonomske evolucije. S obzirom na to da se odvija u realnom vremenu, ekonomska evolucija je prirodno osetljiva na kulturalno-istorijske i socio-psihološke osobenosti (Dosi, 1991, 6).

Savremene artikulacije darvinističke epistemološke paradigme značajnim delom susreću se u konceptu "generalizovanog darvinizma". Darvinizam je u ekonomsku teoriju preuzet iz biologije, tako da su pokušaji njegove razrade kao obrasca promišljanja privredne stvarnosti najpre imali oslonac u spoznatim 
obrascima delovanja evolucionih načela u biološkom svetu (Nelson \& Winter, 1982; Hodgson, 1993). Vremenom je, ipak, preovladalo uverenje da privreda ima suviše veliki obim specifičnosti, da bi se mogle da povlače direktne analogije sa biološkim fenomenima. Umesto nasilnog smeštanja privrednih pojava $u$ biološke darvinističke kalupe, došlo se do primerenije strategije konstituisanja evolucionističke ekonomske paradagme. Naime, ne napuštajući izvorne postavke darvinizma, teži se ka njegovom prečišćavanju od svih sadržaja specifičnih za biološke fenomene, kako bi se došlo do svojevrsnog konceptualnog supstrata, koji bi mogao da posluži kao univerzalni epistemološki obrazac za proučavanje svih pojava čija dinamika ima evoluciona obeležja. Dobijeni generalni okvir treba posebno razraditi za svaku klasu fenomena izloženu evolucionoj dinamici, u skladu sa specifičnim oblicima njenog ispoljavanja. Tako se stiglo do jednog od vodećih tokova evolucione ekonomske misli, poznatog kao generalizovani darvinizam, koji se gotovo pretvara u posebnu granu evolucionističke ekonomije (Dollimore \& Hodgson, 2014).

Najopštije posmatrano, generalizovani darvinizam objedinjava nastojanja da se darvinistički pristup generalizuje do nivoa epistomološkog obrasca koji je podoban za proučavanje svih sistema koji su podložni evolucionoj dinamici i, u skladu s tim, poseduju određene ontološki unificirajuće karakteristike biološke, društvene i dr. Shodno tome, tzv. univerzalni darvinizam ili generalizovani darvinizam trebalo bi da opiše fenomene koji imaju svojstva tzv. „kompleksnih populacionih sistema“ (Hodgson, 2007, 265-266). Kompleksni populacioni sistemi trebalo bi da imaju sledeća svojstva: njih nastanjuju populacije međusobno različitih jedinki, suočenih sa lokalno ograničenim resursima i problemom opstanka; neka adaptivna rešenja generisana $u$ borbi za opstanak mogu biti zadržana kroz vreme i preneta na druge jedinke, kroz široko definisane mehanizme koji obezbeđuju delovanje principa nasleđivanja (Hodgson, 2007).

Artikulisanje univerzalnog darvinizma kao generalnog epistemološkog okvira, u raznim oblastima, na različite kompleksne populacione sisteme na koje se on može odnositi, mora da uvažava njihove osobenosti. $\mathrm{U}$ tom smislu, razrada generalizovanog darvinizma $\mathrm{u}$ ekonomskoj teoriji mora da ima zadatak iznalaženja specifičnih mehanizama koji, u skladu sa univerzalnim darvinističkim načelima, oblikuju evoluciju u privredi. Shodno tome, treba odgovoriti na pitanja mehanizma generisanja varijacija, prirode selekcionog mehanizma i kriterijuma, mehanizma nasleđivanja i dr. (Aldrich, Hodgson, Hull, Knudsen, Mokyr \& Vanberg, 2008, 584-585). Suštinski važan zadatak evolucione ekonomije je određivanje entiteta koji nosi ekonomsku evoluciju, čiju sposobnost opstanka testira selekcioni pritisak, dugoročno posmatrano. Taj bi entitet trebalo da ima sposobnost intergeneracijskog prenošenja svojih osobina, slično genima u biološkoj evoluciji. Upravo je genotip suštinska "meta“ evolucije, dok su njen neposredni predmet konkretne jedinke koje nose gene, i u biologiji prezentuju fenotip. U modernijoj evolucionističkoj terminologiji, ova dva entiteta konceptualizuju se kao replikator i interaktor (Aldrich et al, 2008). Replikacija predstavlja kauzalnu vezu između entiteta gde postoji suštinska sličnost između replikovanih jedinki i originala i gde se na njih prenosi i informacija o rešenjima vezanim za opstanak. Replikator je entitet koji prenosi svoju strukturu uglavnom kao „netaknutu“ kroz sukcesivne replikacije (Hull, 1988, 408). S druge strane, interaktor je entitet koji direktno, kao koheziona celina, stupa u reakcije sa okruženjem, na način da interakcija postaje diferencijalna (Hull, 1988, 408). Selekcioni proces identifikuje se kao diferenijalni nestanak ili proliferacija interaktora, koja u konačnom vodi ka diferencijalnoj perpetuaciji odgovarajućih replikatora (Hull, 1988, 409), što se događa na više, međusobno povezanih, nivoa sistema na kojima se ispoljava evoluciona dinamika.

Dakle, glavni akter ekonomske evolucije trebalo bi da bude entitet koji je dovoljno trajan, ima sposobnost replikacije, i nosi određena rešenja u borbi za opstanak. Popularna verzija evolucionističke ekonomije smatra da ulogu replikatora imaju navike i rutine, a da su glavni kandidati za interaktora firme i slične kohezione organizacije (Hodgson \& Knudsen, 2004). Navike predstavljaju dispozicije za određene vrste ponašanja, koje su nastale ponavljanjem, misonim ili bihevioralnim, a pohranjene su $\mathrm{u}$ čovekovom nervnom sistemu. Te dispozicije se pretvaraju $u$ ponašanje samo $u$ određenim okolnostima. Navike 
su kao dispozicije dovoljno trajne da bi bile predmet evolucije, a istovremeno imaju i sposobnost replikacije, imitiranja (Hodgson \& Knudsen, 2004, 286-289). Važna determinanta transformacije navika u ponašanje jesu institucije. Upravo društvene institucije stabilizuju i kanališu navike i ponašanje (Hodgson \& Knudsen, 2004, 289). Rutine predstavljaju organizacione dispozicije koje mogu stimulisati određene obrasce ponašanja pojedinaca unutar grupe, koji, sa svoje strane, istovremeno sadrže i sekvencijalne odgovore na podsticaje. U organizacijama dolazi do mešanja navika njihovih članova, u smislu da su navike jednog člana okruženje za drugog, tako da takvo okruženje može biti podsticaj za neka nova ponašanja koja mogu da dovedu do promena ili replikacije delova tog okruženja (Hodgson \& Knudsen, 2004). Rutine se mogu smatrati i koherentnim skupovima navika koje, kada su podstaknute okolnostima, vode sekvencijalnom ponašanju unutar grupe. I navike i rutine podložne su delovanju evolucionih principa varijacije, herediteta i selekcije.

U ponuđenom modelu, opstanak uspešnijih firmi istovremeno predstavlja i selektivnu retenciju njihovih poslovnih rutina, što posledično ima određenog uticaja na odabir navika radnika od kojih su pomenute organizacione dispozicije komponovane, pa samim tim, ultimativno, i ka nekoj vrsti selekcije samih radnika, odnosno, njihovih genetskih struktura (što se onda izjednačava i sa „izvornim“ konceptom biološke evolucije). Postoji dakle, više vrsta replikatora - rutine, navike, geni - i više nivoa na kojima selekcija deluje - firme i pojedinci. Navedeni selekcioni niz, već i u izloženoj uopštenoj formi, u izvesnom smislu nagoveštava postojanje određene vrste sinhroniciteta biološke i društveno-ekonomske evolucije, ali se prilikom razmatranja potonje vrste evolucione dinamike mogu ignorisati selekcioni tokovi na nivou bioloških replikatora (Hodgson, \& Knudsen, 2004, 302).

Naročito važnu ulogu u prethodno opisanoj konceptualizaciji generalizovanog darvinizma imaju navike, s obzirom na to da predstavljaju gradivni element više nivoa sistema na kojima deluje evolutivna selekcija. Najpre, navike su replikaciona struktura na nivou pojedinaca kao aktera društveno-ekonomskih procesa. Takođe, koherentno sjedinjavanje navika različitih pojedinaca unutar formi vodi ka stvaranju rutina, kao viših entiteta replikacije. Koncept navike je ovde preuzet iz američke filozofije pragmatizma i nekadašnje instinktivne psihologije, $u$ smislu dispozicija za određene vrste ponašanja, koje se stiču kroz razne mehanizme socijalne interakcije, pri čemu se replikacija (koja nije savršena) izražava na fenotipskom nivou (ponašanje), a ne genotipskom (genetski definisana psihološka stanja pojedinaca). Dalja klarsifikacija pomenutog koncepta našla je oslonca u koncepciji programski zasnovanog ponašanja. U procesu traganja za dovoljno ubedljivom alternativom koncepciji racionalnog izbora, V. J. Vanberg (2002) objedinjava nalaze različitih disciplina: evolutivne biologije, epistemologije, psihologije i teorije ograničene racionalnosti. Saznanja iz pomenutih oblasti o čovekovom ponašanju vode ka zaključku da je ono, na neki način, kodirano, programski upravljano. Ukupni kapacitet čoveka za odlučivanje, koncentrisan u ljudskom umu, ima trojako poreklo: genetsko nasleđe, lično iskustvo i socijalno-kulturološka evolucija. Raspoloživi repertoar sposobnosti odlučivanja formira se kroz selektivnu eliminiciju obrazaca ponašanja koji ne donose uspeh. Sva mudrost čoveka, prema tome, produkt je prošlosti, adaptacija na ranija okruženja koje su prošle evolucioni odabir, dok je sav inkrement u postojećem znanju rezultat iskoraka iz postojećih gnoseoloških kapaciteta, koji se zasniva na principu pokušaja i grešaka (Campbell, 1965, prema: Vanberg, 2002). Strukture koje u pomenutom smislu obezbeđuju podršku ljudskom odlučivanju, organizovane su kao svojevrsni programi, specijalizovani za pojedine klase problema, uključujući i socijalne odnose (među važnijima su detektovanje transakcija i izbegavanje onih koji izigravaju obaveze) (Vanberg, 2002, 37). Ostaje otvoreno pitanje kakvo je relativno učešće u ljudskom umu programa dobijenih genetičkim nasleđem u i onih generisanim ličnim učenjem i socijalnokulturnim iskustvom. U kontekstu prikazane verzije generalizovanog darvinizma, koncepcija ljudske svesti kao modularne strukture, komponovane od instrukcija genetskog i socijalno-kulturalnog porekla, nalazi mesta u objašnjenju navika. Kao okosnica društvenoekonomske evolucije, navike se mogu smatrati naročitim oblikom programa u smislu saznanja iz pomenutih disciplina (Aldrich et al, 2008, 590). 


\section{KRITIKA GENERALIZOVANOG DARVINIZMA I TEZA O KONTINUITETU}

Izložena generalizacija darvinističke paradigme i način njenog upodobljavanja prema zahtevima proučavanja privredne stvarnosti, ne nailazi na najširu podršku evolucionističke naučno-istraživačke zajednice unutar ekonomske teorije. Primedbe se upućuju metodu izgradnje pomenutog epistemološkog obrasca, ali i samom koncipiranju ekonomske evolucije kao procesa koji se odvija prema darvinističkom modelu. Osporovanja generalizovanog darvinizma u ekonomskoj teoriji značajnim delom potiču od rivalskog toka evolucionističke misli u ekonomiji, poznatog kao teza o kontinuitetu.

Teorijska argumentacija koja podupire tezu o kontinuitetu kao svoje polazište ima kritički odnos prema preslikavanju darvinističkih prinicipa na analizu ekonomskih procesa. U tom smislu, ukazuje se na neopravdanost korišćenja selekcionog mehanizma u objašnjenju ekonomske evolucije (Cordes, 2007, 136-141). Najpre se ističe da je priroda adaptacionih mehanizama u biološkom i ekonomskom domenu različita. Dok su adaptacije bioloških jedinki produkt slučajnih genetskih mutacija i seksualnih rekombinacija, ekonomski entiteti imaju sposobnost direktnog $\mathrm{i}$ svesnog reagovanja na impulse iz okruženja, tako da čak mogu umanjiti selekcione pritiske. Nadalje, kritikuje se tretman firmi kao jedne od formi interaktora u privredi, kao i pripisivanje rutinama replikatorskog svojstva. Ističe se da su firme u stanju da menjaju svoje rutine, dok takva relacija između interaktora i replikatora u biološkim sistemima nije moguća. Takođe, problematično je shvatanje rutina kao replikatora, s obzirom na njihovu nedovoljnu trajnost, jer se one u poslovnim procesima menjaju relativno brzo i često. Kao principijelna zamerka navodi se neprimerenost koncepta prirodne selekcije, jer su ekonomski akteri u stanju da svesno biraju organizacione oblike obezbeđenja opstanka, saglasno sopstvenim kriterijumima selekcije. Shodno navedenom, protagonisti teze o kontinuitetu kritikuju generalizovani darvinizam zbog nekritičkog povlačenja analogija između ekonomskih i bioloških procesa (Witt, 2004, 128).

Temeljno polazište protagonista teze o kontinuitetu jeste ono o postojanju ontološkog i istorijskog kontinuiteta između biološke i kulturološke evolucije, iako se njihovi mehanizmi principijelno razlikuju. Kulturološka evolucija odvija se prema sebi svojstvenim zakonitostima, ali na osnovama koje je prethodno postavila prirodna selekcija, u vidu urođenih ljudskih osobina (Cordes, 2007, 141). Evolucija se u navedenom pristupu definiše kao samotransformacija određenog sistema, koja je vođena određenim zakonitostima. U toku filogenije ljudske vrste, prirodna selekcija dovela je do formiranja takvog sklopa osobina koji je ljudima obezbedio znatno veće stope reprodukcije $u$ odnosu na druge vrste. Kao posledica toga, znatno je oslabio selekcioni pritisak, što je, sa svoje strane, dovelo do stvaranja uslova za druge vrste evolucije: kulturološku, ekonomsku, tehnološku (Witt, 2004, 132). Rezultat prirodne selekcije je da se inputima iz okruženja, materijalima i energiji, dodaje i prirodnom selekcijom oblikovano genetičko znanje ljudi, kao input koji se samotransformiše, kroz nastanak i širenje inovacija. Rastuće ljudsko znanje koje se intergeneracijski akumulira bilo je od odlučujućeg uticaja na proizvodnju, oblikujući na taj način i ekonomsku evoluciju. Važnu ulogu u narastanju ljudskog znanja imala su razna sredstva unapređenja njegovog širenja, kao što su pisana komunikacija, pronalazak tehnologije štampanja i savremenih načina replikacije znanja. Takođe, prisutan je i problem sve slabije uklopljenosti ljudski generisanih tokova materijala $\mathrm{i}$ energije $\mathrm{u}$ tokove prirode, kao bitno ograničenje budućih civilizacijskih učinaka ekonomske evolucije (Witt, 2004, 141).

Zastupnici teze o kontinuitetu ocenjuju da postavka o homologiji bioloških i ekonomskih procesa, koja se prema tumačenju ovog teorijskog pravca logično može izvesti iz generalizovanog darvinizma, nije realistična. Takođe, iznosi se stav da je generalizacija darvinizma u ekonomskoj nauci pokazala malo interesovanja za empirijsku potvrdu sopstvenog shvatanja evolucione dinamike (Levit et al, 2011).

Kao što se iz izloženog može zaključiti, evolucionistički tok ekonomske misli zapravo je konglomerat različitih gledišta o mogućem obrascu evolucije privrednog procesa. Treba, svakako, napomenuti da i unutar same darvinističke verzije ekonomskog evolucionizma postoje alternativne konceptualizacije ekonomske evolucije (Pelikan, 2011). 


\section{GRUPNA SELEKCIJA, INSTITUCIJE I EKONOMSKA KOORDINACIJA}

Trebalo bi na ovom mestu istaći da, čak i kada se ne posmatra sa strogo darvinističkog stanovišta, ekonomska evolucija predstavlja višenivovski proces. Njoj su izloženi svi entiteti koji tvore ontologiju društvenih procesa. Konsekventno, mora se uzeti $\mathrm{u}$ obzir evoluciona dinamika i onih fenomena koji predstavljaju odraz kolektivne dimenzije ljudskog delovanja. Tu se dolazi do problema grupne selekcije, koji i danas predstavlja veliki izazov za evolucionu teoriju. Nameće se, naime, pitanje mogućnosti opstanka grupe, $s$ obzirom na to da je $u$ evolucionom smislu, ona, po pravilu, sastavljena od "sebičnih" pojedinaca, koji će u borbi za opstanak dovesti do njene razgradnje. Preciznije, potreban je kritičan nivo kooperacije, koji bi suzbio sebičnost pojedinaca do nivoa koji bi obezbedio opstanak grupe. Posmatrano kroz aktuelnu darvinističku shematiku, ukoliko su grupe interaktor, onda mora da postoji nekakva replikaciona struktura koja obezbeđuje odgovarajući balans između urođene sebičnosti članova grupe i kooperacije potrebne za njen opstanak, što se označava i kao problem identifikacije tzv. „socijalnog replikatora“ (Campbell, 1965).

Bez namere da se ovde detaljnije ulazi u problematiku grupne selekcije, može se konstatovati da su upravo institucionalne strukture podobno konceptualno rešenje $u$ smislu nalaženja socijalnog replikatora. Potrebno je, naime, značajno prisustvo regulacionih mehanizama radi održanja za opstanak grupe neophodnog nivoa kooperacije pojedinaca, među kojima su od naročite važnosti oni koji utiču na poverenje. Tek u režimu izvesnosti ponašanja partnera u socijalnoj interakciji, pre svega, u domenu poštovanja pravila, akteri će biti podstaknuti na kooperativne aranžmane. Poverenje je svojevrsno „nevidljivo tkanje“ kooperativnog ponašanja jedinki unutar grupe i kao takvo predstavlja deo neformalne institucionalne regulacije. Važnost ovog atributa institucionalnog dizajna društva je snažno potvrđena upravo u sferi ekonomskih transakcija, koje mogu biti značajno sputane usled oportunističkog ponašanja, loše postavljenih principal-agent odnosa, asimetričnih informacija i sl. (Lekovic, 2012, 65). Nivo poverenja potreban za održanje kohezije ekonomskih odnosa, međutim, i sam zavisi od podrške drugih društvenih institucija (Lekovic, 2012, 66). Možda se već iz izloženog može naslutiti kardinalan uticaj združenog dejstva institucionalnih struktura na ekonomsku evoluciju, i, povezano sa tim, diferencijalni opstanak privrednih ,jedinki“ različitog nivoa, što govori u prilog njihovog izbora kao mogućeg konceptualnog nosioca funkcije replikatora privrednog procesa.

Iako je rodonačelnik ekonomskog evolucionizma, T. Veblen je institucije smatrao centralnom temom evolucione teorije privrednih tokova, $\mathrm{u}$ kasnijim darvinističkim konceptualizacijama one bivaju delimično istisnute iz središta interesovanja. Ostaje otvoreno pitanje da li će postojeći intenzitet i razgranatost istraživanja svrstanih $\mathrm{u}$ teorijski korpus evolucionističke ekonomije, dovesti i do pomaka $\mathrm{u}$ artikulisanju uloge institucionalnih struktura $\mathrm{u}$ evolucionoj dinamici. U tom smislu, ovde će biti skicirane još dve reprezentativne koncepcije, koje teže ka revitalizaciji uloge institucija u konceptualizovanju ekonomske evolucije.

U novijoj verziji svoje teorije ekonomske evolucije, P. Pelikan privredu konceptualizuje kao skup agenata na različitim ontološkim nivoima hijerarhije. Agenti višeg reda nastaju kao emergentni entitet, samoorganizacijom agenata nižeg reda $u$ mreže (Pelikan, 2011). Svi agenti imaju ugrađene instrukcije o ponašanju u obliku pravila. U privredi, relevantni agenti su pojedinci, organizacije i privreda (Pelikan, 2011). Pojedinci raspolažu instrukcijama u obliku kognitivih kapaciteta dobijenih genetskom evolucijom i kulturološkim iskustvom, dok su pravila organizacija i privrede, zapravo, formalne i neformalne institucije. Promene institucionalnih pravila kroz pokušaje i greške predstavljaju evoluciju, dok dinamika unutar mreža agenata nižeg reda, pod okriljem postojećih institucija, predstavlja proces privrednog razvoja (Pelikan, 2011).

Protagonisti evolutivne makroekonomije privredu smatraju rasutom strukturom koja transformiše energetski input, pretvarajući ga u output. Sistem karakteriše neravnoteža, ali i homeostaza, prisutna su neprekidna nastojanja da se privlači što više energije, kako bi se održao dinamizam sistema (Foster, 2011). Dezintegraciju sistema sprečavaju mezo-pravila, koja 
obezbeđuju kratkoročno stabilne makroekonomske tokove. Ta su pravila hijerarhijski ustrojena, i mogu se prepoznati u institucijama društva (Foster, 2011). Dele se na fizička, koja daju znanja o transformaciji energetskog input-a, i socijalna, koja diktiraju ponašanje prema drugim agentima. Privredni rast je moguć samo ekspanzijom investicija usmerenih ka inovacijama, a to je moguće samo promenom mezopravila (Foster, 2011). Drugim rečima, evolucija mezopravila, odnosno, institucija, blisko je povezana sa putanjom privrednog rasta različitih društava.

Nezavisno od pomenutih razmatranja, ako se možda i ne mogu egzaktno identifikovati kao nosioci ekonomske evolucije, društvene institucije mogu se makar smatrati njihovom relativno upotrebljivom aproksimacijom. Shvaćene kao pravila igre u društvu, koja strukturišu društveno-ekonomske interakcije (North, 1994), institucije su čvorište čitavog snopa za privredu bitnih funkcija - od onih koje determinišu ponašanje aktera, preko obezbeđenja kanala njihove komunikacije, sve do oblikovanja tehnoloških kapaciteta društva.

Centralni problem funkcionisanja privrede je obezbeđenje ekonomske koordinacije. U svojoj antologijskoj elaboraciji pomenutog pitanja, F. Hayek je ukazivao na nemogućnost da bilo koji pojedinac, ili kolektivni organ raspolažu ukupnošću ekonomski relevantnog znanja. Postoji, međutim, mehanizam koji premošćava problem nedovoljnog znanja ekonomskih aktera, i omogućava da njihovo delovanje ipak na neki način bude uređeno. Radi se o sistemu tržišnih cena, čije pulsiranje pruža uvid u relativnu oskudnost resursa i time signalizuje ekonomskim akterima poželjni smer njihove alokacije (Hayek, 1948). Usmeravanjem resursa na razne, cenovnim sistemom određene, delotvorne upotrebe, $u$ uslovima neizvesnosti i nepotpunog znanja aktera, tržište daje nezamenljiv doprinos ekonomskoj koordinaciji i održavanju privrede na stabilnim, ravnotežnim trajektorijama. F. Hayek ukazuje i na druge, spontano izrasle i kroz dugotrajnu praksu oblikovane institucionalne strukture koje, $\mathrm{u}$ sadejstvu sa tržištem, obavljaju društveno-ekonomsku koordinaciju: jezik, novac, moral, pravo (Hayek, 1960). F. Hayek-ova efektna analiza bacila je svetlo na koordinaciju kao težišnu funkciju institucionalnih struktura. Njen je oslonac, svakako, u tržišnom mehanizmu, kome potporu pružaju i druge društvene institucije. Slično tržištu, one na neki način "dešifruju“, okruženje, stvaraju predstavu kod aktera kako je ono strukturisano i koji su poželjni obrasci delovanja.

Pružajući informaciono utočište akteru u uslovima neizvesnosti, institucije nadomeštaju njegove saznajne limite i omogućavaju mu smisleno ekonomsko delovanje (North, 1981).

Shodno navedenom, svaka se privreda može smatrati osobenim sklopom tržišta i drugih institucija u službi društveno-ekonomske koordinacije. Svetsku privredu nastanjuju brojne i bogato izdiferencirane vantržišne institucije, čija su heterogenost i koordinacioni učinci odraz različitih putanja kulturološko-istorijske evolucije pojedinih društava. Pored toga što predstavlja sveprisutnu, i nesumnjivo dominantnu koordinacionu strukturu, ni samo tržište ne spada u red „naturalnih“ kategorija, već $u$ kolekciju institucija izniklih $u$ procesu društveno-ekonomske evolucije. I više od toga, tržišni mehanizam predmet je kontinuiranog kolektivnog uticaja, usmerenog na oblikovanje njegovih mnogostranih uticaja u skladu sa društvenim interesima. Razniinstitucionalni kapaciteti uključeni su u kolektivna nastojanja da se u određenoj meri ograniči uticaj tržišta na društveno prihvatljivu distribuciju moći između relevantnih ekonomskih aktera. Primera radi, netržišne institucije (naročito, sudske), mogu biti uposlene u procesu iznalaženja fer-pravila za rešavanje permanentnih konflikata generisanih tržišnom razmenom (Commons, 1968/1924, prema: Vanberg, 1997). Vantržišne institiucionalne strukture, same po sebi, predstavljaju i neku vrstu odbrane društva od socijalne destrukcije koju, u određenim civilizacijskim etapama, zakonito izaziva generalizacija tržišnog mehanizma (Polanyi, 1944). Posmatranje tržišta kao naturalnog, nadinstitucionalnog entiteta, zamagljuje stvarni način njegovog funkcionisanja, koje nosi pečat kulturalno-istorijskih okolnosti (Dugger, 2005).

\section{ZAKLJUČAK}

Polazište rada, u smislu prezentovane građe, pokazuje se kao održivo. Čak i nezavisno od argumentacije prikazane $\mathrm{u}$ radu, razne grane ekonomske analize 
detektuju postojanje raznovrsnih institucionalnih struktura, koje, u sadejstvu sa tržištem, omogućavaju ekonomsku koordinaciju na raznim nivoima privrede. Indukovana selekcionim pritiskom, njihova dinamika se, u manjoj ili većoj meri, ispoljava kao trajektorijski zavisni fenomen, u konvencionalnoj ekonomskoj analizi označen kao „put zavisnosti“. Talas neoliberalnih reformi, usmeren ka apsolutizaciji tržišnog mehanizma, nosi značajan destruktivni potencijal, s obzirom da frontalni atak na postojeće raznorodne netržišne institucije u svetskoj privredi, preti da ozbiljno umanji njen budući adaptivni kapacitet.

Valorizacija institucionalnih struktura unutar evolucionističkog toka ekonomska misli, možda još uvek $u$ potpunosti ne odražava njihov mnogostran i kapitalan uticaj na evoluciju privrede. Još snažnija senzibilizacija na institucionalnu komponentu ekonomske evolucije možda može povećati delotvornost evolucionističkog promišljanja privrede. Neke od istraživačkih orijentacija, značajno osvešćenih u pomenutom smislu, su evolutivna teorija privrednog rasta, komparativna politička ekonomija, teorija nacionalnih inovacionih sistema i dr. Ekonomska politika, takođe, mora da razume moguće implikacije ovog elementa privrednog procesa, kako bi se njegovo dejstvo moglo, u granicama mogućeg, da kanališe u skladu sa potrebama razvoja privrede.

Ne treba, međutim, očekivati ozbiljniju penetraciju evolucionističkog pristupa u glavni tok ekonomske misli. Najpre, mimo sasvim okvirnih epistemoloških načela, ne nazire se skora konvergencija alternativnih verzija ekonomskog evolucionizma $u$ jedinstven i konzistentan paradigmatski okvir. Postavlja se, nezavisno od toga i pitanje recepcije pomenutog pristupa od strane ekonomske ortodoksije, odgovorne za diseminaciju tema i ideja kroz većinski deo ekonomsko-teorijske zajednice, koja pokazuje slabo interesovanje za koncepcije koje nisu prošle kroz rigoroznu matematičku formalizaciju. Evolucionisički pristup ostaje i dalje veoma prikladan $\mathrm{u}$ okolnostima kada je potrebno napraviti iskorak iz konvencionalne ekonomske analize ka proučavanju realnih ekonomskih sistema, čija je dinamika kontekstualno-specifična i podložna kulturno-istorijskim zakonomernostima. Tim više, promišljanje privrede $u$ evolucionističkim okvirima, može biti podoban orijentir za ekonomsku politiku.

\section{ZAHVALNICA}

Ovaj rad deo je Projekta osnovnih istraživanja (br. 179066), koji finansira Ministarstvo prosvete, nauke i tehnološkog razvoja Republike Srbije.

\section{REFERENCE}

Aldrich, H. E., Hodgson, G. M., Hull, D. L., Knudsen, T. Mokyr, J., \& Vanberg, V. J. (2008). In Defence of Generalized Darwinism. Journal of Evolutionary Economics, 18(5), 577-596. doi: 10.1007/s00191-008-0110-z

Campbell, D. T. (1965). Variation and Selective Retention in Sociocultural Evolution. In H. R. Barringer, G. I. Blankstein, \& R. W. Mack, (Eds.), Social Change in Developing Areas: A Reinterpretation of Evolutionary Theory. Cambridge M.A.: Schenkman.

Commons, J. 1968 (1924). Legal Foundations of Capitalism. Madison: The University of Wisconsin Press.

Cordes, C. (2007). Turning Economics into an Evolutionary Science: Veblen, the Selection Metaphor, and Analogical Thinking. Journal of Economic Issues, 41(1), 135-154.

Dennett, D. C. (1995). Darwin's Dangerous Idea: Evolution and the Meanings of Life. London, UK: Penguin Books.

Dollimore, D., \& Hodgson, G. (2014). Four Essays on Economic Evolution: An Introduction. Journal of Evolutionary Economics, 24(1), 1-10. doi: 10.1007/s00191-013-0315-7

Dosi, G. (1991). Some Thoughts on the Premises, Challenges and Dangers of an Evolutionary Perspective in Economics. Journal of Evolutionary Economics, 1(1), 5-7.

Dugger, W. M. (2005). Dugger's Theorem: The Free Market is Impossible: Remakrs upon Receiving the Veblen-Commons Award. Journal of Economic Issues, 39(2), 309-324.

Foster, J. (2011). Evolutionary Macroeconomics: A Research Agenda. Journal of Evolutionary Economics, 21(1), 5-28. doi: 10.1007/s00191-010-0187-z

Hayek, F. (1948). Individualism and Economic Order. Chicago, USA: University of Chicago Press. 
Hayek, F. (1960). The Constitution of Liberty. Chicago. USA: University of Chicago Press.

Hodgson, G. M. (1993). Economics and Evolution: Bringing Life Back into Economics. Michigan, USA: University of Michigan Press.

Hodgson, G. M. (1994). Economic Evolution and Natural Selection. In G. M., Hodgson, W. J., Sammuels, \& M. R.Tool, (Eds.), The Elgar Companion to Institutional and Evolutionary Economics. Cheltenham, Northampton: Edward Elgar Publishing.

Hodgson, G. M. (1995). The Evolution of Evolutionary Economics. Scottish Journal of Political Economy, 42(4), 469-488. doi:10.1111/j.1467-9485.1995.tb01172.x

Hodgson, G. M. (1998). On the evolution of Thorstein Veblen's evolutionary economics. Cambridge Journal of Economics, 22(4). 415-431.

Hodgson, G. M. (2007). A Response to Christian Cordes and Clifford Poirot. Journal of Economic Issues, 41(1), 265-276.

Hodgson, G. M. (2008). How Veblen Generalized Darwinism. Journal of Economic Issues, 42(2), 399-405.

Hodgson, G. M., \& Knudsen, T. (2004). The Firm as an Interactor: Firms as Vehicles for Habits and Routines. Journal of Evolutionary Economics, 14(3), 281-307. doi: 10.1007/s00191004-0192-1

Hull, D. L. (1988). Science as a Process: An Evolutionary Account of the Social and Conceptual Development of Science. Chicago, USA: The University of Chicago Press Books.

Lekovic, V. (2012). Trust as an institutional factor of economic success. Economic Horizons, 14(2), 65-78. doi: 10.5937/ ekonhor1202063L

Levit, G., S., Hossfeld, U., \& Witt, U. (2011). Can Darwinism be "Generalized" and of what use would this be? Journal of Evolutionary Economics, 21(4), 545-562. doi: 10.1007/s00191011-0235-3

Nelson, R. (2002). Bringing Institutions into Evolutionary Growth Theory. Journal of Evolutionary Economics, 12(1-2), 1728. doi: 10.1007/s00191-002-0108-x

Nelson, R., \& Winter, S. (1982). Evolutionary Theory of Economic Change. Cambridge Mass. and London: The Belknap Press of Harvard University Press.

North, D. C. (1981). Structure and Change in Economic History.
New York, NY: London, UK: W. W. Norton Company.

North, D. C. (1990). Institutions, Institutional Change and Economic Performance. Cambridge, USA: Cambridge University Press.

North, D. C. (1994). Economic Performance through Time. American Economic Review, 84(3), 359-368.

Pelikan, P. (2003). Bringing Institutions into Evolutionary Economics: Another View with Links to Changes in Physical and Social Technologies. Journal of Evolutionary Economics, 13(3), 237-258. doi: 10.1007/s00191-003-0157-9

Pelikan, P. (2011). Evolutionary Developmental Economics: How to generalize Darwinism Fruitfully to help comprehend Economic Change. Journal of Evolutionary Economics, 21(2), 341-366. doi: 10.1007/s00191-010-0178-0

Polanyi, K. (1944). The Great Transformation: The Political and Economic Origins of Our Time. Boston, USA: Beacon Press.

Rutherford, M. (1998) Veblen's Evolutionary Programme: A Promise Unfulfilled. Cambridge Journal of Economics, 22(4), 463-477

Stoelhorst, J. W. (2008a). Generalized Darwinism from the Bottom Up: An Evolutionary View of Socio-Economic Behavior and Organization. In W. Elsner, \& H. Hanappi, (Eds.), Advances in Evolutionary Institutional Economics: Evolutionary Mechanisms, Non-Knowledge, and Strategy (pp. 35-58). Cheltenham: Edward Elgar Publishers.

Stoelhorst, J. W. (2008b) The Explanatory Logic and Ontological Commitments of Generalized Darwinism. Journal of Economic Methodology, 15(4), 343-363. doi: 10.1080/13501780802506661

Vanberg, V. J. (1997). Institutional Evolution through Purposeful Selection: The Constitutional Economics of John R. Commons. Constitutional Political Economy, 8(2), 105-122. doi: 10.1023/A:1009030324594

Vanberg, V. J. (2002). Rational Choice vs. Program-Based Behavior: Alternative Theoretical Approaches and their Relevance for the Study of Institutions. Rationality and Society, 14(1), 7-54. doi: 10.1177/1043463102014001002

Veblen, T. (1998/1898). Why is Econonomics not an Evolutionary Science. Cambridge Journal of Economics, 22(4), 403-414.

Witt, U. (2004). On the Proper Interpretation of "Evolution" in Economics and its Implications for Production Theory. Journal of Economic Methodology, 11(2), 125-146. doi: 10.1080/13501780410001694091 
Primljeno 15. jula 2015, nakon revizije, prihvaćeno za publikovanje 17. avgusta 2015.

Elektronska verzija objavljena 25. avgusta 2015.

Zoran Stefanović je vanredni profesor na Ekonomskom fakultetu Univerziteta u Nišu. Izvodi nastavu iz predmeta Ekonomske doktrine i Ekonomika tranzicije (osnovne studije), Savremene ekonomske teorije (master studije) i Tranzicija postsocijalističkih privreda (doktorske studije). Oblasti njegovog istraživačkog interesovanja su savremene ekonomske paradigme, ekonomika tranzicije i politička ekonomija globalizacije.

\title{
THE COORDINATION ASPECT OF INSTITUTIONS IN THE CONTEXT OF AN EVOLUTIONARY APPROACH TO ECONOMIC DYNAMICS
}

\author{
Zoran Stefanovic \\ Faculty of Economics, University of Nis, Nis, The Republic of Serbia
}

The paper provides an insight into the dominant trends of contemporary evolutionary economics and outlines the important issues related to the articulation of this approach in thinking about the economy. The paper also affirms a proposition on institutions as carrier structures of socio-economic evolution, whose numerous effects at the societal level are decoded through the coordination function. In addition to the market, the process of coordination also employs other non-market institutional structures, whose profile and operational principles are the product of the trajectories of cultural and historical evolution, different among social orders. Projects aimed at the transformation of the economic system are to be sensitized to an objectively conditioned diversity of the institutional structures of the world economy, and in this sense, should be very careful in the installation of "universal" reform solutions.

Keywords: generalized Darwinism, replicator, interactor, institutions, coordination

JEL Classification: B15, B25, B52, E02, E14 